\title{
Prediction of Underground Space Development Function of Existing Industrial District in City Based on CA-Markov Model
}

\author{
Xiaochun Hong ${ }^{1, *}$, Xiang Ji 1,2,* \\ ${ }^{1}$ School of mechanics and civil engineering, China university of mining and technology, Xuzhou 211116, China \\ ${ }^{2}$ Jiangsu collaborative innovation center for building energy saving and construction technology, Xuzhou 211116, China
}

\begin{abstract}
Scientific analysis of the spatial evolution of existing industrial areas in cities and prediction of future development needs will help to rationally allocate land resources in existing industrial areas in urban renewal, scientifically and rationally develop underground space, and promote the sustainable development of existing industrial areas. First of all, the development mode and leading function type of the existing industrial zone in the city are sorted out, and its corresponding underground space development function is further sorted out. It is found that the underground space development of the existing industrial zones in the city is closely related to the dominant functions and location of the ground renewal. To scientifically guide the development of underground space in existing industrial areas in cities, this study proposes a method based on the dynamics model and the CA-Markov model to predict the functions of underground space development in existing industrial areas in cities, which will improve the efficiency and Benefits to promote the rational allocation of land resources is of great significance.
\end{abstract}

\section{Introduction}

With the expansion of the city, some industrial relics with a high cultural value that were originally located at the edge of the city and gradually in the center of the city have gradually become an important part of the construction of urban characteristics. As a product of urban modernization, urban underground space plays a vital role in urban expansion, traffic pressure relief, and urban environment improvement. Existing urban industrial areas, as key objects of urban renewal, provide valuable land resources for the expansion of urban space. Through the development and utilization of the underground space of existing urban industrial areas, not only the dual goals of industrial land renewal and industrial historical heritage protection can be achieved, but also the urban space capacity will be improved and the conflict between land resource shortage and urban development will be alleviated. The establishment of a scientific method for predicting the functions of underground space in existing urban industrial zones is the key basis.

\section{Literature review}

In the renewal of existing industrial areas, the development of underground space plays a significant role in expanding urban land capacity, improving the urban functions of industrial relics, and promoting the integration of updated plot functions into the city [1]. Zhang Yue (2005) analyzed the effect of underground space development on the historical and cultural protection areas of Beijing's old city, and proposed multiple renewal models of historic districts based on underground space development [2], but did not verify the specific effects of these renewal models. Huang Leilei (2010) analyzed the principles, functions, development models, and spatial layout of underground space development in the renewal of the old city's industrial heritage sites based on the underground space development behavior in the renewal of the Sulun site in Suzhou, and found that underground space development was effectively promoted The integrity of the surface industrial heritage and the improvement of the vitality of the area [3], and then proposed the development guidelines for the development focus, development scope, and development intensity of the existing industrial zone in the context of protection [4,5]. Liu Jieyi et al. (2012) proposed a variety of underground space development strategies combined with heritage protection based on the concept of industrial heritage reuse. This industrial heritage protection method can increase land value and protect industrial heritage, and improve the sustainable development of urban industrial heritage and economic benefits. Obvious advantages in other aspects [6]. Zhao Yi (2015) arranged commercial, entertainment, warehousing, and municipal functions on the first basement floor, some commercial, parking, rail transit stations, air defenses, etc. on the second floor underground, parking, rail transit lines, and equipment rooms. The underground space development method set in the three underground floors promotes urban renewal, and the underground space should be reasonably developed under the intensity of ground development [7].

* Corresponding author: hongxiaochun00@163.com 
Table1. Summary of main cases of renewal of existing urban industrial zones in China

\begin{tabular}{|c|c|c|c|c|c|c|c|c|c|c|}
\hline Cases & $\begin{array}{c}\text { Long } \\
\text { Museu } \\
\text { m }\end{array}$ & $\begin{array}{c}\text { Oil } \\
\text { Tank }\end{array}$ & B-LINK & $\begin{array}{c}\text { MIFA } \\
1862\end{array}$ & $\begin{array}{l}\text { Elite } \\
\text { Valley }\end{array}$ & $\begin{array}{l}\text { Hero } \\
\text { World }\end{array}$ & $\begin{array}{l}\text { Olympics } \\
\text { Plaza }\end{array}$ & $\begin{array}{l}\text { Su Lun } \\
\text { Factory }\end{array}$ & $\begin{array}{c}\text { Yuzhou } \\
\text { Factory Site }\end{array}$ & $\begin{array}{c}\text { Art } \\
\text { Porcelain } \\
\text { Factory }\end{array}$ \\
\hline Location & $\begin{array}{c}\text { Shangha } \\
\mathrm{i}\end{array}$ & $\begin{array}{c}\text { Shangha } \\
\mathrm{i}\end{array}$ & Shanghai & $\begin{array}{c}\text { Shangha } \\
\text { i }\end{array}$ & $\begin{array}{c}\text { Shangha } \\
\mathrm{i}\end{array}$ & Shanghai & Beijing & Suzhou & Jingdezhen & Jingdezhen \\
\hline $\begin{array}{c}\text { Spatial } \\
\text { location }\end{array}$ & $\begin{array}{c}\text { City } \\
\text { Center }\end{array}$ & $\begin{array}{c}\text { City } \\
\text { Center }\end{array}$ & City Center & $\begin{array}{l}\text { City } \\
\text { Center }\end{array}$ & $\begin{array}{c}\text { City } \\
\text { Center }\end{array}$ & Suburbs & Suburbs & $\begin{array}{c}\text { City } \\
\text { Center }\end{array}$ & City Center & City Center \\
\hline $\begin{array}{c}\text { Development } \\
\text { model }\end{array}$ & $\begin{array}{l}\text { Public } \\
\text { space }\end{array}$ & $\begin{array}{l}\text { Public } \\
\text { space }\end{array}$ & $\begin{array}{l}\text { Comprehensiv } \\
\text { e development }\end{array}$ & $\begin{array}{l}\text { Public } \\
\text { space }\end{array}$ & $\begin{array}{l}\text { Public } \\
\text { space }\end{array}$ & $\begin{array}{c}\text { Comprehe } \\
\text { nsive } \\
\text { developme } \\
\text { nt }\end{array}$ & $\begin{array}{c}\text { Comprehensi } \\
\text { ve } \\
\text { development }\end{array}$ & $\begin{array}{l}\text { Business } \\
\text { service }\end{array}$ & $\begin{array}{l}\text { Business } \\
\text { service }\end{array}$ & $\begin{array}{l}\text { Business } \\
\text { service }\end{array}$ \\
\hline $\begin{array}{c}\text { The extent of } \\
\text { historical } \\
\text { features }\end{array}$ & fine & fine & fine & fine & fine & fine & fine & fine & fine & fine \\
\hline $\begin{array}{l}\text { Function } \\
\text { matching } \\
\text { situation }\end{array}$ & fine & fine & good & ordinary & fine & ordinary & good & good & fine & fine \\
\hline $\begin{array}{c}\text { Landscape } \\
\text { environment }\end{array}$ & fine & fine & ordinary & fine & fine & ordinary & good & ordinary & good & good \\
\hline $\begin{array}{c}\text { Transportatio } \\
\text { n Facilities }\end{array}$ & ordinary & ordinary & good & fine & fine & fine & fine & fine & fine & fine \\
\hline Overall effect & ordinary & fine & fine & ordinary & ordinary & ordinary & good & good & fine & fine \\
\hline
\end{tabular}

Table2. Functional types of underground space in existing urban industrial areas

\begin{tabular}{|c|c|c|c|c|c|c|}
\hline \multirow[b]{2}{*}{ Cases } & \multicolumn{3}{|c|}{ Form of traffic } & \multirow{2}{*}{ Exhibition space } & \multirow{2}{*}{ Commercial space } & \multirow[b]{2}{*}{ Other public spaces } \\
\hline & Rail transit & Underground parking & Underground lane & & & \\
\hline Long Museum & & $\sqrt{ }$ & & & & \\
\hline Oil Tank Art Center & & & & $\sqrt{ }$ & $\sqrt{ }$ & $\sqrt{ }$ \\
\hline B-LINK & & $\sqrt{ }$ & & & $\sqrt{ }$ & $\sqrt{ }$ \\
\hline MIFA 1862 & & & & $\sqrt{ }$ & & \\
\hline Elite Valley & & $\sqrt{1}$ & & & & \\
\hline Hero World & & $\sqrt{ }$ & & & & \\
\hline The 2022 Winter Olympics Plaza & & $\sqrt{1}$ & & $\sqrt{ }$ & $\sqrt{ }$ & \\
\hline Su Lun Factory & $\sqrt{ }$ & $\sqrt{1}$ & & & $\sqrt{ }$ & \\
\hline Yuzhou Factory Site & & $\sqrt{ }$ & & & $\sqrt{ }$ & $\sqrt{ }$ \\
\hline Art Porcelain Factory & & $\sqrt{ }$ & & & & \\
\hline
\end{tabular}

However, the underground space development in the renewal of existing industrial areas is not only affected by its own needs, but also by the development needs of the surrounding cities, and its underground space functions are also closely related to the ground renewal.

\section{Existing urban industrial zone development model and leading functions of underground space}

The main purpose of underground space development in existing urban industrial areas is to alleviate the contradiction between protection and renewal and the shortage of land resources, increase space capacity, improve regional functions, and improve environmental quality. Table 1 summarizes several representative cases in which my country has expanded the capacity of existing industrial areas through the development of underground space. It is clearly seen that the current renewal of existing industrial areas in China is mainly based on industrial tourism and creative industrial parks.

Existing urban industrial areas, as industrial historical relics, have distinctive cultural and historical resources, and are an important part of the city or region. The development of underground spaces has added some functions to better highlight the location and urban image, Bringing many opportunities for differentiated development of cities. Through the development and utilization of underground space, while protecting the urban texture on the ground, it also makes up for the lack of space, expands the urban capacity, drives regional development, and promotes better realization of renewal. Table 2 lists the types of underground space functions in existing urban industrial areas. The most common functions for developing underground spaces in existing urban industrial areas are underground parking and underground commerce. This aspect is driven by the protection of the surface features of existing urban industrial areas. Proper commercial development has also promoted the improvement of the economic benefits of existing urban industrial zones. Combined with the case situation in Table 1, it is seen that multi-functional development of underground space development functions based on meeting parking and commerce is an important way to improve the overall effectiveness of existing urban industrial areas.

Although underground parking and underground commercial development are common development methods in existing urban industrial areas, it is not difficult to find that there is an obvious alignment relationship between underground space and ground space, as shown in Figure 1. The selection of underground space functions corresponding to these different modes is affected by many factors. For example, from the perspective of regional development, when existing urban industrial areas that have been renewed are at the center of future urban development, they are simply from the perspective of space demand at this stage Setting out for underground space planning and design is difficult to meet the needs of future development. Urban traffic development trends corresponding to different traffic conditions also have a significant impact on the underground space development of existing urban 
industrial areas. Therefore, the use of scientific methods to simulate the evolution of the spatial structure of existing urban industrial areas is to judge the current and future development of existing urban industrial areas. Need and determine the scientific basis for the development of underground space in existing urban industrial zones.

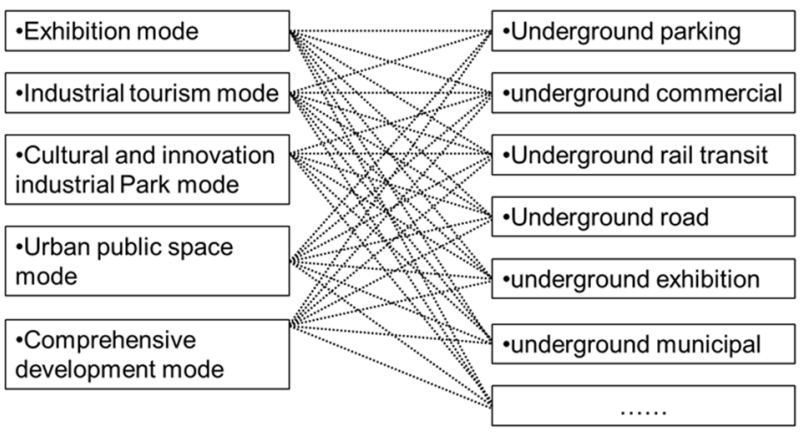

Fig1. Correspondence between ground development model and underground space.

\section{Prediction of underground space development function based on the dynamic model and CA-Markov model}

Based on the historical and current data of the existing urban industrial zone, using GIS technology, dynamic model and Markov model, analyze the evolution of the territorial spatial structure of the existing urban industrial zone, and discuss its changing laws; use the CA-Markov model to predict the existing The spatial pattern of land in urban industrial zones can reveal the Spatiotemporal evolution characteristics of the land in existing urban industrial zones. This Spatiotemporal evolution feature is the basis for the prediction of underground space development functions.

\subsection{Land and space identification}

At present, there are two common spatial identification methods, namely, merge classification method and quantitative measurement algorithm. The former is based on the current land use data, and the current data is merged and classified. The advantage is that the land function classification can be related to the current research area planning. The latter needs to construct an index system that meets the actual situation of the study area, and combine the index evaluation method to classify the land space type [8]. Due to the quantification of indicators and the differences between regions, comprehensive factors make this method not universal. Comprehensive comparison, merging The classification method is less difficult to apply, and it can be connected with the land classification system of the study area. Therefore, this study adopts the merged classification method.

\subsection{Dynamic model of territorial space}

The dynamic degree of land space is a reflection of the degree of changes in land space in different periods. The speed and amplitude of various spatial changes are usually expressed in a single-dynamic degree within a region, which can be reflected in a certain category during the research period. Other land spaces are transformed into other types of spatial activity[9], and the expression is:

$$
K=\frac{S_{i}-S_{i i}}{S_{i i}} \times \frac{1}{\gamma} \times 100 \%
$$

In the formula, $\mathrm{K}$ is the single dynamic index of a certain land space within a certain period time; $\mathrm{Si}$ is the area after a certain type of land space has been transferred, and $\mathrm{Sii}$ is the area when this type of land space has not been transferred; $\mathrm{T}$ is the study duration, this study Is the number of years. The comprehensive dynamic index is used to indicate the strength of the land space change in the study area, reflecting the comprehensive influence of people's development of space and other activities on the change of the land space structure. The expression is:

$$
G=\frac{\sum_{i=1}^{n} \Delta S_{i-j}}{2 \sum_{i=1}^{n} S i} \times \frac{1}{T} \times 100 \%
$$

In the formula, $\mathrm{G}$ is the comprehensive dynamic index of the territorial space within a certain period of time; $\triangle$ $\mathrm{Si}-\mathrm{j}$ is the absolute value of the area of the i-th type of territorial space utilization type converted to other territorial space types during the study period, and $\mathrm{Si}$ is the absolute value of the area at the beginning of the study period. Type $i$ area of land space utilization type.

\begin{tabular}{|c|c|c|}
\hline Development model & Specific mode & Function type \\
\hline Cultural development & $\begin{array}{l}\text { Museum, Cultural and Creative } \\
\text { Park }\end{array}$ & $\begin{array}{c}\text { Underground exhibition hall, underground garage, } \\
\text { underground commerce, underground storage, sunken space } \\
\text { for public activities }\end{array}$ \\
\hline Residential development & Residential community & Underground parking, underground storage \\
\hline $\begin{array}{c}\text { Business service } \\
\text { development }\end{array}$ & $\begin{array}{l}\text { Commercial streets, shopping } \\
\text { centers, etc. }\end{array}$ & $\begin{array}{l}\text { Comprehensive consideration of functions such as } \\
\text { underground commerce and transportation facilities }\end{array}$ \\
\hline Business office development & $\begin{array}{l}\text { Urban industrial park, high- } \\
\text { tech industrial park }\end{array}$ & $\begin{array}{l}\text { Mainly underground garage, taking into account other } \\
\text { supporting facilities }\end{array}$ \\
\hline Leisure tourism development & City parks, industrial tourism & $\begin{array}{l}\text { Mainly underground garage, taking into account commercial } \\
\text { and municipal facilities; sunken space for public activities }\end{array}$ \\
\hline Comprehensive development & $\begin{array}{l}\text { Urban RBD, mixed function } \\
\text { park }\end{array}$ & $\begin{array}{l}\text { Coordinate the development of underground space, including: } \\
\text { underground parking, cultural, commercial and other facilities }\end{array}$ \\
\hline $\begin{array}{c}\text { Other public facilities } \\
\text { development }\end{array}$ & School, medical, sports, etc. & $\begin{array}{l}\text { Mainly underground garage, taking into account other } \\
\text { supporting facilities }\end{array}$ \\
\hline
\end{tabular}

Table3. Appropriate functions of underground spaces in existing urban industrial zones of different development types 
Table4. Suggestions on the future development function of underground space in existing urban industrial areas

\begin{tabular}{|c|c|c|c|c|c|c|}
\hline \multirow{2}{*}{ Cases } & \multirow{2}{*}{\multicolumn{3}{|c|}{ Form of traffic }} & \multirow{2}{*}{ Exhibition space } & \multirow{2}{*}{ Commercial space } & \multirow{2}{*}{$\begin{array}{c}\text { Other public } \\
\text { spaces }\end{array}$} \\
\hline & Rail transit & & & & & \\
\hline Long Museum & & $\checkmark$ & $\circ$ & & & \\
\hline Oil Tank Art Center & & & & $\sqrt{ }$ & $\sqrt{ }$ & $\mathrm{v}$ \\
\hline B-LINK & & $\checkmark$ & 。 & & $\checkmark$ & $\checkmark$ \\
\hline MIFA 1862 & & & & $\sqrt{ }$ & & o \\
\hline Elite Valley & $\circ$ & $\mathrm{v}$ & . & & $\circ$ & $\circ$ \\
\hline Hero World & $\circ$ & $\checkmark$ & $\circ$ & & $\circ$ & $\circ$ \\
\hline The 2022 Winter Olympics Plaza & 。 & $\checkmark$ & & $\checkmark$ & $\checkmark$ & 。 \\
\hline Su Lun Factory & $\checkmark$ & $\checkmark$ & 。 & & 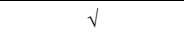 & $\circ$ \\
\hline Yuzhou Factory Site & & $\checkmark$ & & & $\checkmark$ & $\mathrm{v}$ \\
\hline Art Porcelain Factory & & $\sqrt{ }$ & $\circ$ & & $\circ$ & $\circ$ \\
\hline
\end{tabular}

Remark: " $\sqrt{ }$ 'Indicates the existing underground space function of the existing urban industrial zone," $\circ$ "Indicates new features in the future

\subsection{CA -Markov model}

\subsubsection{Principle of the CA model}

CA (Cellular Automata) consists of 4 parts: cell and cell state, neighborhood, and conversion rules.

The smallest unit of calculation; the state refers to the cell category; the neighborhood structure determines the conversion state of the current cell; the conversion rule is the cell conversion method. CA is a spatiotemporal dynamic simulation model in which space, time, and state are discretized. The general CA model formula is as follows [10]:

$$
\mathrm{S}_{(\mathrm{t}+1)}=\mathrm{f}\left(\mathrm{S}_{(\mathrm{t})}, \mathrm{N}\right)
$$

In the formula, $\mathrm{S}$ is a finite and discrete state set of cells; $\mathrm{N}$ is the neighborhood of the cell; $\mathrm{t}$ and $\mathrm{t}+1$ represent two different moments; f represents the state transition rule.

\subsubsection{Markov transition matrix principle}

The Markov model is studied by the method of probability theory. It is in a random time series, using a mathematical model to perform matrix analysis of time, and estimate the future possibility based on the current state and the trend of change. The Markov model can be expressed by the following formula [10]:

$$
\mathrm{A}_{\mathrm{n}}=\mathrm{A}_{\mathrm{n}-1} \mathrm{XP}_{\mathrm{ij}}
$$

In the formula, An and An-1 are the state of the land and space at two moments; Pij is the state transition probability matrix. Determining the state transition probability matrix is the key step of the model research, which can be expressed by the following formula [10]:

$$
P=\left[\begin{array}{ccc}
P_{11} & \cdots & P_{1 n} \\
\vdots & \ddots & \vdots \\
P_{n 1} & \cdots & P_{n n}
\end{array}\right]
$$

In the formula, $\mathrm{P}$ is the probability of land space type conversion, each row in the matrix is the probability of land space type transferring to other types, and each column in the matrix is the probability of land space type being transferred from other types.

\subsubsection{CA -Markov model}

The CA-Markov model is a dynamic model with discretetime, space, and state. Its birth combines the advantages of Markov model time dimension analysis and CA model space dimension analysis. It is an important research method of nonlinear science. [10].

\subsubsection{Prediction of functions of underground space in existing industrial areas based on the CA-Markov model}

Based on the CA and Markov model, we can intuitively analyze the development history, current situation, and future trends of existing industrial areas, and propose suitable functions for the development of underground space in existing urban industrial areas corresponding to different surface development models, see Table 3, combining surface development models and underground space development The function correspondence table, and the corresponding future underground space development functions of existing urban industrial parks are proposed in Table 4.

\section{Conclusion}

Urban renewal has become the main direction of urban development in China[11]. The renewal of existing urban industrial areas in busy cities has an indelible effect on the value enhancement of existing industrial areas and the enhancement of urban functions. This study builds a CAMarkov model to predict the development trend based on the objective laws of existing urban industrial zones and urban development. According to the development trend and the base characteristics and development suitability characteristics of existing urban industrial zones, the future development of underground space functions is proposed. Direction, to provide theoretical support for guiding the scientific development of existing urban industrial zones and the rational construction of underground space.

\section{Acknowledgements}

This research was funded by the National Key $R \& D$ 
Program Projects of China, grant number 2018YFC0704903 and National Natural Science Foundation of China, grant number 51778611 .We greatly thank all participating experts, the visually impaired and volunteers.

\section{References}

1. Huang Leilei, Cao Yuna. Development and Utilization of Underground Space in Old City Industrial Heritage Area[J]. Tianjin Construction Technology, 2010, 20(2):18- 19.

2. Zhang Yue. Research on the Development and Utilization of Underground Space in Beijing Old City Historical and Cultural Protection Area[D]. Beijing: Beijing University of Technology, 2005.

3. Huang Leilei. Research on the Development and Utilization of Underground Space in Old City Industrial Heritage Area[D]. Suzhou: Suzhou Institute of Science and Technology. 2010.

4. Xia Jian, Wang Yong, Huang Leilei. Research on Underground Space Development Planning Strategies of Old City Industrial Heritage in the Context of Protection[J]. Journal of Suzhou University of Science and Technology: Engineering and Technology Edition, 2015, 28(3): 65-69 .

5. Xia Jian, Wang Yong. Research on the integrated development of underground space in the industrial heritage area of the old city based on overall protection[J]. Huazhong Architecture, 2016, 34. (4):17-20.

6. Liu Jieyi, Xia Jian, Shen Qing. Discussion on the protection of industrial cultural heritage combined with the development of underground space[J]. Chinese Journal of Underground Space and Engineering, 2012(2):5-10+17.

7. Zhao Yi. Research on the renewal strategy of Ningbo urban center from the perspective of inventory planning[D]. Hangzhou: Zhejiang University, 2015.

8. Xue B, Xiao X, Li J. Identification method and empirical study of urban industrial spatial relationship based on POI big data: a case of Shenyang City, China[J]. Geography and Sustainability, 2020, 1(2): 152-162.

9. Adhikari S, Southworth J. Simulating forest cover changes of Bannerghatta National Park based on a CA-Markov model: a remote sensing approach[J]. Remote Sensing, 2012, 4(10): 3215-3243.

10. Fu X, Wang X, Yang Y J. Deriving suitability factors for CA-Markov land use simulation model based on local historical data[J]. Journal of environmental management, 2018, 206: 10-19.

11. Hong Xiaochun. Historical evolution, current situation and development trend of space planning [J]. Journal of $\mathrm{xi}$ 'an university of architecture and technology (social science edition),2020,39(02):2030 . 